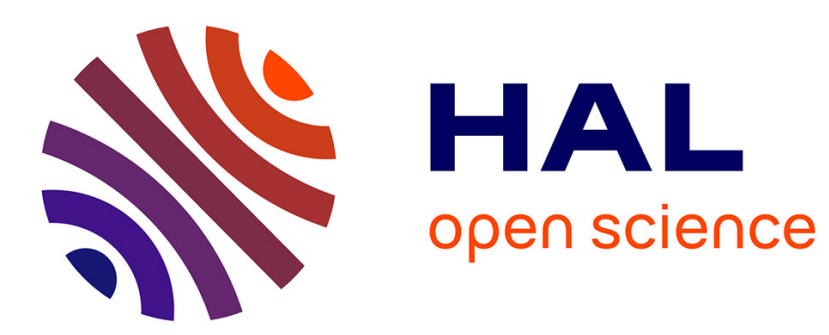

\title{
LINEAR CHAIN MODELS AND SOUND VELOCITIES IN MOLECULAR ORGANIC CRYSTALS \\ C. Ecolivet
}

\section{> To cite this version:}

C. Ecolivet. LINEAR CHAIN MODELS AND SOUND VELOCITIES IN MOLECULAR ORGANIC CRYSTALS. Journal de Physique Colloques, 1981, 42 (C6), pp.C6-578-C6-580. 10.1051/jphyscol:19816168 • jpa-00221246

\section{HAL Id: jpa-00221246 https://hal.science/jpa-00221246}

Submitted on 1 Jan 1981

HAL is a multi-disciplinary open access archive for the deposit and dissemination of scientific research documents, whether they are published or not. The documents may come from teaching and research institutions in France or abroad, or from public or private research centers.
L'archive ouverte pluridisciplinaire HAL, est destinée au dépôt et à la diffusion de documents scientifiques de niveau recherche, publiés ou non, émanant des établissements d'enseignement et de recherche français ou étrangers, des laboratoires publics ou privés. 
LINEAR CHAIN MODELS AND SOUND VELOCITIES IN MOLECULAR ORGANIC CRYSTALS

C. Ecolivet

Groupe de Physique Cristalline, E.R.A. au C.N.R.S. no070015, Université de Rennes, Campus de Beaulieu, 35042 Rennes Cedex, France

Abstract Longitudinal sound velocities in crystals of elongated aromatic molecules have been measured by Brillouin scattering and are found to be faithfully described by a simple linear chain model, whereas a similar behaviour is observed for compressibility and thermal expansion. A particular attention has been paid to the p-polyphenyls and polyacenes series.

1. INTRODUCTION Despite the width of the aromatic rings; p-polyphenyls and polyacenes are good examples of chain-like molecules which crystallizes in parallel stacks, themselves parallel to the molecular long axis. This kind of stacking is far from being unusual in molecular and specially in flat molecules crystals which most of the time belong to the monoclinic $\mathrm{P} 2_{1} / a$ symmetry group. This is exactly what happens for naphtalene, biphenyl, dibenzyl and many others.

We will consider here a simple chain model for crystals of molecules composed of a various number of aromatic rings and look at the sound longitudinal velocities along the stacking direction, intra and intermolecular bonds will be represented by springs of force constants resp. $\mathrm{K}_{1}$ and $\mathrm{K}_{2}$.

2. LONGITUDINAL SOUND VELOCITIES IN p-POLYPHENYLS and POLYACENES Let us

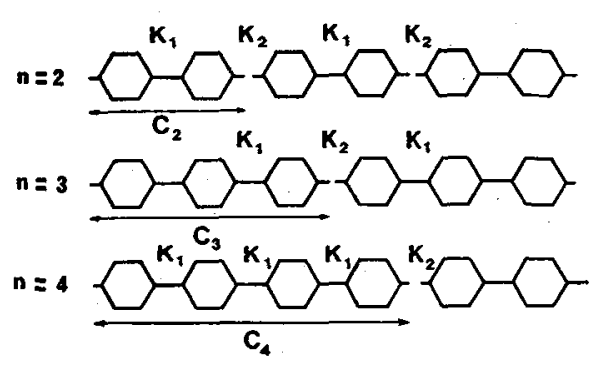

Fig. 1 Polyphenyls chain model for longitudinal wave propagation. consider first the p-polyphenyls which are xepresented on Fig. 1 as a function of the molecular ring number ; the $c_{n}$ parameter being the length of the crystallographic period.

It can be shown very easily that the longitudinal sound velocity along the molecular Iong axis can be written for a molecule with $n$ rings as :

$$
v_{n}=\frac{c_{n}}{\sqrt{M_{n}\left(\frac{1}{K_{2}}+\frac{n-1}{K_{1}}\right)}}
$$

Where $M_{n}$ is the mass of the molecule.

The $k_{1}$ value can be obtained from $I . R$. experiments on biphenyl which frequency mode is about $334 \mathrm{~cm}^{-1}$ this gives $\mathrm{K}_{1} \simeq 450 \mathrm{~N} / \mathrm{m}$. We repoxt in Table 2 the $\mathrm{K}_{2}$ values 
obtained at $300 \mathrm{~K}$ and $5 \mathrm{~K}$ of the 3 first elements of the polyphenyls series from sound velocities obtained by Brillouin scattering $\left({ }^{1}\right)$.

\begin{tabular}{|r|c|c|c|}
\hline$n$ & 2 & 3 & 4 \\
\hline$C_{n}(\AA)$ & 9.51 & 13.62 & 17.85 \\
$N_{A} M_{n}(g)$ & 154 & 230 & 306 \\
\hline $300 \mathrm{k}\left(\begin{array}{c}V_{n}(\mathrm{~m} / \mathrm{s}) \\
K_{2}(\mathrm{~N} / \mathrm{m})\end{array}\right.$ & 3940 & 4730 & 5210 \\
\hline $5 \mathrm{k}\left(V_{n}(\mathrm{~m} / \mathrm{s})\right.$ & 4.49 & 4.60 & 4.32 \\
\hline$K_{2}(\mathrm{~N} / \mathrm{m})$ & 6.11 & 5440 & 6010 \\
\hline
\end{tabular}

Table 1 Intermolecular force constant $\mathrm{K}_{2}$ for biphenyl p-terphenyl, p-quaterphenyl at room temperature and near liquid helium temperature.

We see on this table an excellent agreement at low tempexature when vibrations are more harmonic, it is also noticeable that the effect of $k_{1}$ is negligible and it should only be detectable for $n>10$.

\begin{tabular}{|c|c|c|cc|}
\hline$n$ & 2 & 3 & \\
\hline$C_{n}(\AA)$ & 8.66 & 11.16 & a) TESLENKO & $\left({ }^{2}\right)$ \\
$N_{A} M_{n}(g)$ & 130 & 178 & b) AFANASSIEVA & \\
\hline$V_{n}(m / s)$ & $3540^{\mathrm{a}}$ & $3860 \mathrm{c}$ & & \\
& $3620 \mathrm{~b}$ & & c) HUNTINGTON & $\left({ }^{3}\right)$ \\
$K_{2}(\mathrm{~N} / \mathrm{m})$ & 3.55 & 3.54 & & \\
\hline
\end{tabular}

Table 2 Intermolecular force constant $\mathrm{K}_{2}$ for naphtalene and anthracene at room temperature.

Table 2 give the same results taken from ultrasonic measurements previously reported in the litterature for the 2 first elements of the polyacenes at room temperature.

From these data one can clearly see that these organic crystals which look rather complicated can be surprisingly well described by simple chain models ; moreover these models also describe the effect of deuteration and the absence of sound velocity variation in directions pexpendicular to the chains when $n$ varies.

\section{COMPRESSIBILITY and THERMAL EXPANSION ANISOTROPIES The Iinear compres-} sibility $\beta$ which can be expressed as a function of the elastic compliance moduli $s_{i k}$ writes down for monoclinic crystals

$$
\beta=A_{1} n_{x}^{2}+A_{2} n_{y}^{2}+A_{3} n_{z}^{2}+A_{5} n_{x} n
$$

where $A_{i}=\sum_{k} S_{i k}$

For all the crystals studied here experimental data show the same anisotropy for compressibility and thermal expansion. A counter example found in the littera- 
ture was dibenzyl and it motivates a new determination of its elastic properties, for the maximum of compressibility found along the molecular long axis looked rather unealistic. Structure, sound velocities compressibility and thermal expansion in the $(\vec{a}, \vec{c})$ plane can be seen on figure 2 .
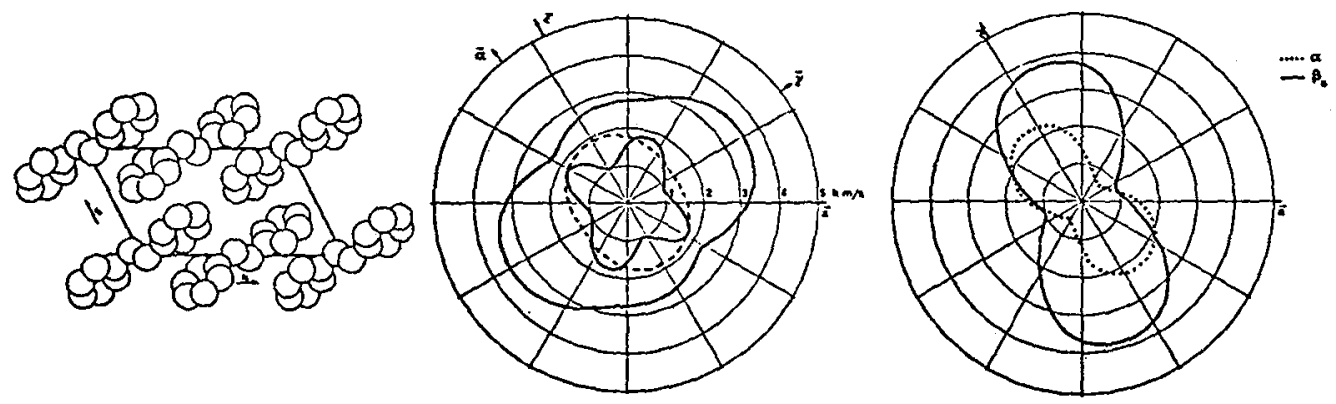

Fig. 2 Structure, sound velocities, linear compressibility and thermal expansion (left to right) of dibenzyl. The dashed curve in the center diagram is related to the transverse mode polarized along $\vec{b}$, whereas the dotted 1 ine in the right diagram corresponds to the thermal expansion $\alpha\left(.2510^{-3} \mathrm{~K}^{-1}\right.$ per division) and the other curve to the linear compressibility $\beta_{\mathrm{s}}\left(15.10^{-12} \mathrm{~m}^{2}\right.$ $N^{-1}$ per division?

This is a typical example of the results we can expect for such kind of crystals where the forces have a short range nature.

\section{References}

1. C. ECOLIVET, Thesis 1981 Rennes.

2. V.F. TESLENKO and G. AFANASSIEVA, quoted in "Molecular Crystals and Molecules" A.I. KITAIGORODSKY Acad. Press New-York, 1973.

3. H.B. HUNTINGTON, S.g. GANGOLI, J.I. Mills, J. Chem. Phys., 50, (1969), 3844. 